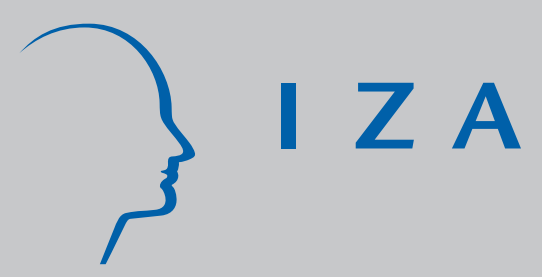

IZA DP No. 1334

How Outsourcing Affects

Bilateral Political Relations

Solomon W. Polachek

October 2004 


\title{
How Outsourcing Affects Bilateral Political Relations
}

\author{
Solomon W. Polachek \\ State University of New York at Binghamton \\ and IZA Bonn
}

Discussion Paper No. 1334

October 2004

\author{
IZA \\ P.O. Box 7240 \\ 53072 Bonn \\ Germany \\ Phone: +49-228-3894-0 \\ Fax: +49-228-3894-180 \\ Email: iza@iza.org
}

\begin{abstract}
Any opinions expressed here are those of the author(s) and not those of the institute. Research disseminated by IZA may include views on policy, but the institute itself takes no institutional policy positions.

The Institute for the Study of Labor (IZA) in Bonn is a local and virtual international research center and a place of communication between science, politics and business. IZA is an independent nonprofit company supported by Deutsche Post World Net. The center is associated with the University of Bonn and offers a stimulating research environment through its research networks, research support, and visitors and doctoral programs. IZA engages in (i) original and internationally competitive research in all fields of labor economics, (ii) development of policy concepts, and (iii) dissemination of research results and concepts to the interested public.
\end{abstract}

IZA Discussion Papers often represent preliminary work and are circulated to encourage discussion. Citation of such a paper should account for its provisional character. A revised version may be available directly from the author. 
IZA Discussion Paper No. 1334

October 2004

\section{ABSTRACT}

\section{How Outsourcing Affects Bilateral Political Relations*}

One issue the literature neglects is how outsourcing stimulates trade (imports, exports and foreign direct investment), thereby affecting political relations. However, at least as far back as 1750, economic philosophers such as Baron de Montesquieu in his L'Esprit des Lois, argued, "peace is the natural effect of trade." This paper first reviews this literature and then presents econometric evidence. The evidence integrates political international relations events data with economics data on bilateral trade. The resulting econometric models show that trade between nations fosters more peaceful dyadic relations.

JEL Classification: F1, F2, J61, M55, O24

Keywords: outsourcing, international trade, peace, conflict, cooperation

Solomon W. Polachek

Department of Economics

State University of New York at Binghamton

Binghamton, New York 13902-6000

USA

Email: polachek@binghamton.edu

\footnotetext{
* This paper is based on my long-term research on conflict and trade. Some is already published in articles listed in the references. Some is on-going.
} 


\section{Introduction}

As a growing number of information technology (IT) jobs moves to India and other countries, the whole issue of outsourcing is becoming an important policy question in the United States. In contrast to the past, when the garment and shoe industries moved much of their manufacturing abroad, current outsourcing involves relatively skilled jobs focusing on specific parts of the production process. Often outsourcing forces many domestic U.S. workers to take lower paying jobs, uproot, retrain or even retire completely. These cause severe hardships for many current employees. On the other hand, outsourcing also has benefits. Reducing corporate production costs by hiring cheaper labor enables companies to stay in business, resulting in higher production and lower prices. As a result, demand is stimulated, and new markets open up. To evaluate the net effect of outsourcing, policy makers have to weigh the short-term costs with the long-term benefits. To help, there is a large literature on the pros and cons of outsourcing. ${ }^{1}$ However, there is one important issue the literature neglects.

The issue, particularly ignored in the economics literature, is how outsourcing affects international political relations. In particular, current literature fails to address what happens to political relations between two countries when one country out sources to the other. However, in 1750, economic philosopher Baron de Montesquieu in his L'Espirit des Loi, argued "peace is the natural effect of trade." If economic philosophers such as de Montesquieu are right, and if outsourcing can be viewed as a type of trade, then outsourcing should foster closer political ties. These closer ties lead to more cooperation and less conflict between the outsourcer and the recipient country.

Political scientists have a long history in studying international relations. Quantitative political scientists utilize data to study issues of conflict and cooperation.

\footnotetext{
${ }^{1}$ For example, see Robert C. Feenstra, (Fall 1998). Also see David Ellwood (2000) and Paul Osterman (2001).
} 
Only recently economists expanded these analyses to get at the effects trade has on bilateral international relations. ${ }^{2}$ This paper reviews the literature on whether trade fosters peace, and then presents econometric evidence. The evidence integrates political international relations events data with economics data on bilateral trade. The resulting econometric models show that more political cooperation than conflict results when countries trade with each other. Thus trade between nations promotes peaceful relations among bilateral trading partners. From these results one can conclude that outsourcing leads to more peaceful bilateral political relations. This is one benefit of outsourcing that current literature does not as yet address.

\section{The Logic}

How does economic interdependence reduce international conflict? The answer is simple: Trade promotes peace because the disruption of trade brought on by conflict makes warfare and other hostilities more costly. Thus, if conflict leads to a diminution of trade, then the cost of conflict (all else constant) is the lost gains from trade. ${ }^{3}$ The higher these gains from trade losses, the more important is trade in deterring conflict and the more important is trade in promoting peace. Thus country pairs with the most trade tend to exhibit the most cooperation and the least hostility. After more formally developing the model, I will present empirical work to support this inverse trade-conflict contention.

\section{Model}

Assume an open economy with $k+1$ countries. Denote an actor country that trades $n$ possible commodities with the $k$ other countries. Domestic consumption of

\footnotetext{
${ }^{2}$ One of the earlier quantitative approaches is presented in Polachek (1980). A related approach is given in Arad and Hirsch (1981). Read (1967) indicates that political policies advocating trade as a means to propagate peace are discussed by a number of $19^{\text {th }}$ century British statesmen, such as Cobden and Bright. Mansfield and Pollins (2003) and Schneider, Barbieri and Gleditsch (2003) contain surveys of recent analytical literature in the field.
} 
commodity i equals domestic production of $q_{i}$ plus imports $m_{i}$ minus exports $x_{i}$. As such,

$$
\begin{aligned}
& c_{i}=q_{i}+m_{i}-x_{i} \\
& m_{i}=\sum_{j=1}^{k} m_{i j} \\
& x_{i}=\sum_{j=1}^{k} x_{i j}
\end{aligned}
$$

where $j$ indexes import and export partners, with $k$ being the number of countries.

Next, define $Z=\left[z_{1}, z_{2}, \ldots, z_{k}\right]$ to depict an actor's conflict vented towards target country $\mathrm{j}$. The actor's welfare function is

$$
W=W(C, Z)=W\left(\left[q_{i}+\sum_{j=1}^{k} m_{i j}-\sum_{j=1}^{k} x_{i j}\right],\left[z_{j}\right]\right)
$$

where the bracketed terms are the commodity and conflict vectors just defined. Including $C$ within the welfare function is obvious. Higher consumption yields greater welfare. Including $\mathrm{Z}$ is unnecessary. However, including $\mathrm{Z}$ merely allows for the possibility of non-economic motivations for conflict or cooperation.

My purpose is to formulate a relationship between economic trade and political conflict. As such, I determine a country's optimal conflict given existing consumption and trade patterns. Depict trade to be the value of exports minus the value of imports. If no balance of payments problems exist then

$$
\sum_{i}^{n} \sum_{j}^{k} x_{i j} P_{x_{i j}}-\sum_{i}^{n} \sum_{j}^{k} m_{i j} P_{m_{i j}}=0
$$

\footnotetext{
${ }^{3}$ The same argument applies when conflict leads to a weakening of the terms of trade, rather than a complete cessation of trade.
} 
where, $P_{x_{i j}}$ depicts unit export prices charged to country j for commodity $\mathrm{i}$ and $P_{m_{i j}}$ is the unit import price charged by country $\mathrm{j}$ for commodity $\mathrm{i}$.

Prices are determined in the international market, but contain at least a component assumed to be dependent on bilateral conflict. Thus

$$
P_{x_{i j}}=f\left(z_{j}\right)
$$

and

$$
P_{m_{i j}}=g\left(z_{j}\right)
$$

such that hostility raises the price that must be paid for imports and lowers the prices at which exports can be sold. Thus,

$$
\begin{gathered}
P_{x_{i j}}^{\prime}=\frac{\partial P_{X_{I J}}}{\partial z_{j}}=f^{\prime}\left(z_{j}\right)<0 \\
P_{m_{i j}}^{\prime}=\frac{\partial P_{m_{i j}}}{\partial z_{j}}=g^{\prime}\left(z_{j}\right)>0 .
\end{gathered}
$$

If conflict such as through embargoes or boycotts leads to the complete cessation of trade then $f^{\prime}=-\infty$ and $g^{\prime}=\infty$, though as will be indicated the net welfare loss associated with foregone trade need not be great if alternative trade avenues exist.

Given this structure as well as predetermined trade, rational behavior on the part of a country's decision makers implies choosing optimal levels of $Z$ that maximize welfare level (4) subject to (1) to (3) and (5) to (9). This implies maximizing the following Lagrangian 
(10) Max

$W=W(C, Z)=W\left(\left[q_{i}+\sum_{j=1}^{k} m_{i j}-\sum_{j=1}^{k} x_{i j}\right],\left[z_{j}\right]\right)+\lambda\left(\sum_{i} \sum_{j} x_{i j} P_{x_{i j}}\left(z_{j}\right)-\sum_{i} \sum_{j} m_{i j} P_{m_{i j}}\left(z_{j}\right)\right)$

First order optimality conditions for optimal conflict requires

$$
\begin{aligned}
& \frac{\partial W}{\partial z_{j}}=\lambda\left(\sum_{i} x_{i j} \frac{\partial P_{x_{i j}}\left(z_{j}\right)}{\partial z_{j}}-\sum_{i} m_{i j} \frac{\partial P_{m_{i j}}\left(z_{j}\right)}{\partial z_{j}}\right)=0 \\
& \frac{\partial W}{\partial \lambda}=\sum_{i} \sum_{j} x_{i j} P_{x_{i j}}\left(z_{j}\right)-\sum_{i} \sum_{j} m_{i j} P_{m_{i j}}\left(z_{j}\right)=0
\end{aligned}
$$

Equation (12) is merely the balance of payments constraint. Equation (11) describes the mechanism by which a country decides on the amount of belligerence. Since the bracketed term is the implicit price of receiving less money for exports while at the same time having to pay more for imports, it represents the net cost associated with extra hostility (MC). This term can be represented graphically (Figure 1) as an upward sloping curve whose position depends on $\mathrm{m}$ and $\mathrm{x}$ levels. In equilibrium, this cost of hostility must just balance the welfare benefit of added hostility $\left(\frac{\partial W}{\partial z_{j}}\right)$ so that the intersection of the $\left(\frac{\partial W}{\partial z_{j}}\right)$ curve and the MC curve depicts equilibrium conflict/cooperation. Note that equilibrium conflict/cooperation levels still arise even if hostility or cooperation implies no welfare gain $\left(\frac{\partial W}{\partial z_{j}}=0\right)$. In this case, optimal conflict is based purely on economic grounds at the point where the MC curve intersects the horizontal axis. If imports or exports are increased, the MC shifts up, thereby implying lower levels of conflict. Thus,

Proposition: The greater an actor country's level of trade with a target, the smaller the amount of actor to target conflict. 


\section{Data}

I employ statistical regression analysis to test this proposition. But first, I describe the data. These data contain information on (1) bilateral political interactions, (2) bilateral trade, and (3) country attributes.

\section{(1) Political Interactions Data}

Events-data comprise bilateral interactions between two countries reported in newspapers and wire services. ${ }^{4}$ Although there are now several such data sets, I concentrate on Edward Azar's Conflict and Peace Data Bank (COBDAB). ${ }^{5}$ COBDAB is an extensive longitudinal collection of about one million daily events reported from 47 newspaper sources between 1948 and 1978. These events are coded on a 15- point scale representing different kinds of conflict and cooperation. (See Table 1 for the annual frequency of events in each category represents the amount of each type bilateral interaction attributable to an actor country vented towards a target country. There are over 105 countries in the sample, and hence about 11 thousand possible bilateral interactions per year. Another newer (1967-1992) events data set is the World Events Interaction Survey (WEIS). However, this is compiled using only the New York Times. Very recent events data are the Kansas Events Data Study (KEDS), which is computer driven and relies solely on wire service reports. Using newer conflict and cooperation data doesn't change the results. ${ }^{6}$

Events data are not free of bias, because they comprise interactions reported only in the media. Many secret treaties and negotiations as well as country dealings not reported in newspapers are obviously omitted. In addition, newspapers often find certain country pairs more newsworthy than others, implying possible selectivity biases. On the other hand, one benefit is events data measure cooperation as well as hostility. Another is

\footnotetext{
${ }^{4}$ The pros and cons of events data are discussed in Kegley (1975).

${ }^{5}$ A detailed description of these data is given in Azar (1980).

${ }^{6}$ Polachek, Seiglie, and Xiang (2004) utilize KEDS data.
} 
that actor and target countries can easily be identified. By using the 15-point scale, the data distinguish the nature of country interactions more precisely than war data or data on defense expenditures.

Finally, one can control for over and underreporting aspects of selectivity by looking at the relative frequency of an event. So over reporting of any one country's events, perhaps because a particular country houses more reporters, can be netted out. The exact measure I choose is the net frequency of conflict (NETF) defined. I define NETF as the frequency of conflictive events (those in category 9 to 15) minus the frequency of cooperative events (those in category 1 to 7 ). ${ }^{7}$ Here, a negative value of NETF implies that more events fall into categories 1 to 7 than 9 to 15 , hence that cooperative interaction exists. A positive value implies that the preponderance of events fall into categories 9 to 15 so that on balance there exists a conflictive relationship. An example of NETF values for a select group of countries is contained in Table 2. The statistical regression results reported later in the paper use NETF as the dependent variable.

\section{(2) Economic Trade}

Ideally one should have bilateral commodity-by-commodity trade flows to fully test the conflict-trade model. Because such data are unavailable, I use aggregate import and export data collected on a country-by-country directional basis. These data are listed in the International Monetary of Fund Directions of Trade annual volumes. They are also available in computer readable format. The trade data are measured in U.S. dollars.

\section{(3) Attribute Data}

I include standardizing variables to adjust for country-specific levels of development that may affect trade and conflict. I merged several international data sets for this purpose. The largest is Banks' Cross-National Time-Series Data Archive.

\footnotetext{
${ }^{7}$ Category 8 contains "neutral" events. I also use weighted net conflict which weights each category by a severity weighting scheme set up by surveying a set of political scientists.
} 


\section{Cross-Sectional Empirical Analysis of the Trade-Conflict Relationship}

The general specification is

$$
N C O N F_{i j t}=f\left(T_{i j t}, A_{i t}, A_{j t}\right)+\varepsilon_{i j t}
$$

where $\mathrm{NCONF}=$ relative conflict of actor country $\mathrm{i}$ toward target country $\mathrm{j}$ in year $\mathrm{t}, \mathrm{T}=$ trade of an actor country $i$ and target country $j, A_{i}=$ a vector of actor country attributes, $A_{j}$ $=\mathrm{a}$ vector of target country attributes, and $\varepsilon=\mathrm{a}$ random error term assumed to be normally distributed with mean 0 . For this specification, $f_{1}^{\prime}<0$ implies that countries with a greater trade dependence engage in less relative conflict. The magnitude of $f_{A}^{\prime}$ reflects how country attributes are related to conflict. They can be thought of as other aspects of the price vector for conflict. For the purposes of this analysis, I neglect describing the impact of country attributes and concentrate solely on the sign and magnitude of $f_{1}^{\prime}$. For now, I also neglect the panel aspects of the data. Thus, I ignore the possibility of country specific parameters. I treat the attribute variables as exogenous identification variables.

Under these assumptions, a consistent pattern appears for these coefficients (Table 3). Independent of the functional form, whether bivariate (Rows (1) and (2)) or multivariate (Rows (3) and (4)), linear (Columns (1)-(5)) or quadratic (Column (6)), there is a negative and statistically significant relationship between conflict and trade. This means that those pairs of countries (denoted by political scientists as dyads) engaged in the most trade have the least conflict even when adjusting for country attributes. The results hold on an annual basis, as well as for pooled cross-sectional regressions.

To assess the empirical significance of this inverse conflict-trade relationship, I compute the elasticity of conflict with respect to trade. These elasticities measure the 
percentage change in conflict brought about by a one percent change in trade. As illustrated (last column), a one percent increase in trade is associated with a decrease in conflict (increase in cooperation) by between 0.15 to 0.19 percent. Thus doubling trade between two countries imply that on average there would be a 15 to 19 percent decline in the relative frequency of conflict.

\section{Implications}

The approach to international relations I outline in this paper analyzes incentives for cooperation. Briefly, I argue that heterogeneous factor endowments necessitate a division of labor based on comparative advantage so that trade patterns emerge among nations. If conflict leads to a cessation (or a diminution of trade through more unfavorable terms) of trade, then those countries with the greatest welfare losses face the highest costs of conflict, and engage in the least conflict and greatest cooperation. I measure welfare via trade levels. I find a strong and robust negative association between conflict and trade. For the most part, country pairs engaged in the most trade have the least conflict.

One can view outsourcing as a form of trade. Workers of a country, say, India, provide the wherewithal to produce a component of a manufactured good more economically than can be done in the manufacturer's country, for example the United States. In turn, the U.S. manufacturer compensates Indian workers for this service. This exchange constitutes trade since the service yields benefits to U.S. consumers, and the payments provide benefits to Indian workers. In turn, the higher Indian and U.S. wealth brought about through this trade enables citizens of both countries to achieve a higher standard of living than otherwise.

Some argue outsourcing is not trade because "there is no reciprocity in outsourcing, only the export of domestic jobs." ${ }^{, 8}$ But this assertion is not valid because U.S. manufacturers benefit directly from cheaper components. Cheaper components lead to lower manufacturing costs, which are passed on the U.S. consumers in terms of higher

\footnotetext{
${ }^{8}$ Paul Craig Roberts, http://www.vdare.com/roberts/free trade notes.htm
} 
quality and lower prices. The implicit increase in wealth means U.S. citizens are better off.

It is well known not all citizens gain. Clearly those U.S. workers forced out of a job because of foreign competition lose. Their well-being diminishes just the same way as workers losing jobs when the U.S. purchases garments and sells wheat, or simply when technological change induces U.S. firms to substitute computers for employees in their production processes. Appropriate transfer payments through the domestic tax system or appropriate government financed retraining could alleviate the hardships, but obviously working out the appropriate subsidies is difficult.

The point of this paper is not to assess the short-term costs and long-run benefits of trade. The point is to bring to the forefront a benefit of trade, and hence a benefit of outsourcing, not well discussed in current literature. In particular, this paper argues that outsourcing results from the trade gains accruing when firms hire foreign workers for part of their production processes. Protecting these trade gains lead countries to cooperate more in their political interactions. As such, trade promotes peace because the disruption of trade brought on by conflict makes warfare and other hostilities more costly. I illustrated this proposition using a theoretical microeconomic model, as well as tested it empirically using events data merged with data on bilateral trade and data on country attributes. 


\section{References}

Arad, Ruth W. \& Seev Hirsch, (1981). 'Peacemaking and Vested Interests: International Economic Transactions', International Studies Quarterly 25 (September): 439-468.

Azar, Edward, (1980). 'The Conflict and Peace Data Bank (COPDAB) Project', Journal of Conflict Resolution 24 (March): 143-152.

de Montesquieu, Baron (1900). The Spirit of Laws, translated by Thomas Nugent, (New York: Collier Press) originally written in 1750 .

Ellwood, David (2000), A Working Nation: Workers, Work, and Government in the New Economy (New York: Russell Sage Foundation);

Feenstra, Robert C. (1998), "Integration of Trade and Disintegration of Production in the Global Economy," Journal of Economic Perspectives 12(4): 31-50.

Gasiorowski, Mark and Solomon Polachek (1982), "Conflict and Interdependence: East-West Trade and Linkages in the Era of Detente," Journal of Conflict Resolution 709-730.

Kegley, C. (ed.) (1975), International Events and the Comparative Analysis of Foreign Policy (Columbia: University of South Carolina Press).

Mansfield, Edward D. and Brian M. Pollins (2003), Economic Interdependence and International Conflict: New Perspectives on An Enduring Debate, (Ann Arbor: University of Michigan Press).

Osterman, Paul (2001), Working in America: A Blueprint for the New Labor Market (Cambridge and London: MIT Press).

Polachek, Solomon W., (1980). 'Conflict and Trade', Journal of Conflict Resolution 24 (March): 55-78.

Polachek, Solomon W., (1992). 'Conflict and Trade: An Economics Approach to Political International Interactions', in Walter Isard and Charles H. Anderton, eds., Economics of Arms Reduction and the Peace Process, New York: Elsevier Science Publishers, pp. 89-120.

Polachek, Solo mon W., (1997). 'Why Democracies Cooperate More and Fight Less: The Relationship Between International Trade and Cooperation', Review of International Economics 5 (August): 295-309.

Polachek, Solomon W. (2002) "Conflict and Trade: An Economics Approach to Political International Interactions With Special Reference to US-China Relations," Paper presented at the Sino-American Economic Relations Under the WTO Conference, Lingnam University, Hong Kong.

Polachek, Solomon W. (2002), “Trade-Based Interactions: An Interdisciplinary Perspective,” $\underline{\text { Conflict }}$ Management and Peace Science, 19(2): 1-21.

Polachek, Solomon W. and Judith A. McDonald (1992), "Strategic Trade and the Incentive for Cooperation," in Disarmament, Economic Conversion, and the Management of Peace, M.Chatterji and L. Forcey, eds, (New York: Praeger Press) 273-84.

Polachek, Solomon, John Robst and Yuan-Ching Chang, (1999). "Liberalism and Interdependence: Extending the Trade-Conflict Model,” Journal of Peace Research, 36(4): 405-422.

Polachek, Solo mon, Carlos Seiglie, and Jun Xiang (2004), “Can FDI Increase Peace as Trade Does?” Paper presented at the AEA Convention, San Diego, California.

Read, D. (1967) Cobden and Bright: A Victorian Political Partnership (London: Edward Arnold), p. 146. 
Reuvany, Rafael (1999-2000). "The Trade Conflict Debate: A Survey of Theory, Evidence and Future Research, Peace Economics, Peace Science and Public Policy” (Winter) 6:23-49.

Reuveny, Rafael \& Heejoon Kang (1996). 'International Trade, Political Conflict/Cooperation, and Granger Causality', American Journal of Political Science 40 (August): 943-70.

Reuveny, Rafael \& Heejoon Kang (1998). 'Bilateral Trade and Political Conflict/Cooperation: Do Goods Matter?' Journal of Peace Research 35 (September): 581-602.

Richardson, Lewis F. (1960), Arms and Insecurity: A Mathematical Study of the Causes and Origins of War, (Pittsburgh: The Boxwood Press and Chicago: Quadrangle Books).

Schneider, Gerald, Katherine Barbieri, and Nils Petter Gleditsch, eds. (2003), Globalization and Armed Conflict, (New York, Toronto and Oxford: Rowman \& Littlefield).

Wright, Quincy (1942), A Study of War, (Chicago: University of Chicago Press). 
Figure 1

Equilibrium Conflict-Cooperation

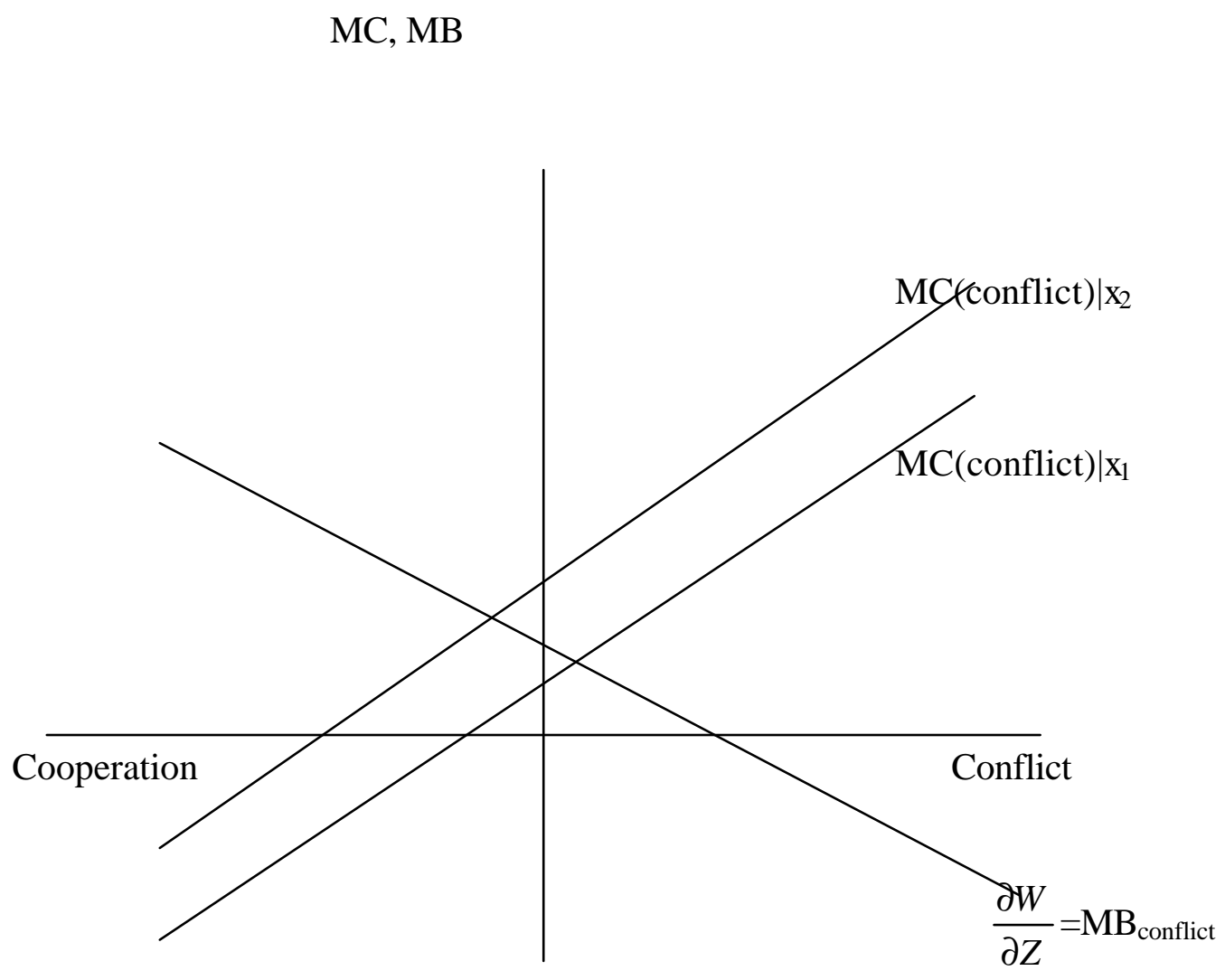


Table 1

\section{COPDAB International Scales}

\begin{tabular}{|c|l|} 
Scale & \multicolumn{1}{|c|}{ Brief Description } \\
\hline 15 & Extensive war acts causing deaths, dislocations and high strategic costs \\
14 & Limited war acts \\
13 & Small scale military acts \\
12 & Political-military hostile acts \\
11 & Diplomatic hostile acts \\
10 & Strong verbal expressions displaying hostility intention \\
9 & Mild verbal edxpression displaying discord in the interaction \\
8 & Neutral or nonsignificant acts for the inter-nation situation \\
7 & Minor official exchanges, talks and policy expression -- mild verbal support \\
6 & Official verbal support \\
5 & Cultural and scientific agreement and support (non-strategic) \\
4 & Non-military technical and industrial agreements \\
3 & Military and strategic support \\
2 & Major strategic alliance \\
1 & Voluntary unification \\
\hline
\end{tabular}


Table 2

Net Conflict for Selected Dyads

\begin{tabular}{lrrrrr} 
& \multicolumn{5}{c}{ Actor } \\
\cline { 2 - 6 } Target & US & $\begin{array}{r}\text { Soviet } \\
\text { Union }\end{array}$ & UK & Egypt & China \\
\cline { 2 - 6 } US & -- & 714 & -304 & -53 & 474 \\
Soviet Union & 476 & -- & 286 & -277 & 233 \\
Canada & -112 & -22 & -68 & -3 & -37 \\
UK & -373 & 254 & -- & 307 & 13 \\
W. Germany & -259 & 113 & -142 & -27 & -22 \\
E. Germany & 54 & -128 & 25 & -39 & -24 \\
Egypt & -63 & -277 & 307 & -- & -85 \\
Israel & -216 & 108 & 16 & 2317 & 21 \\
China & 240 & 93 & 56 & -64 & - \\
Japan & -175 & -47 & -34 & -17 & -80 \\
\hline
\end{tabular}

Source: COPDAB for years 1948-78. Positive numbers reflect net conflict and negative numbers reflect net cooperation. 
Table 3

The Trade-Conflict Relationship by Year

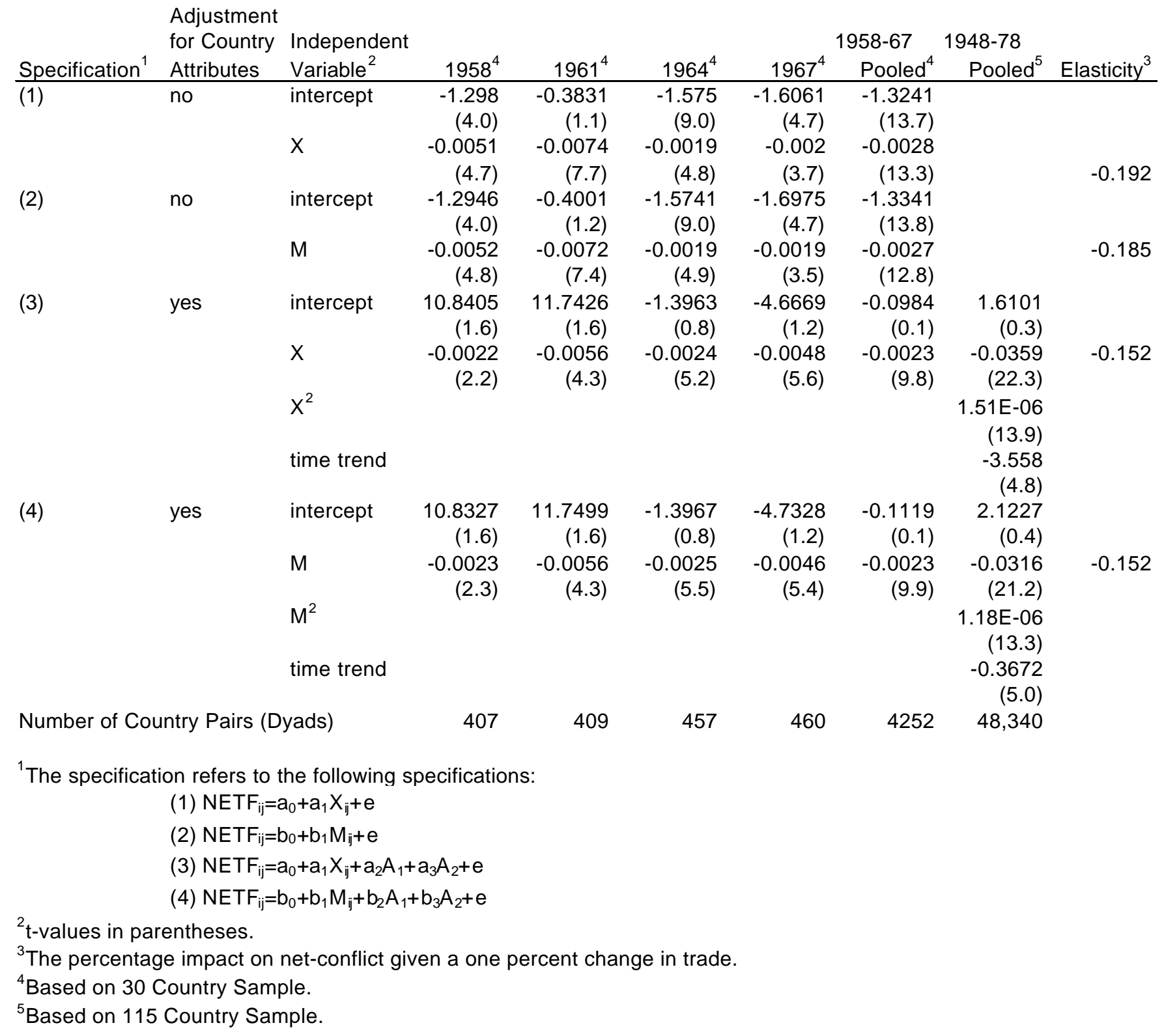

